\title{
Food insecurity and overweight among government-backed economy restaurant workers
}

\author{
Insegurança alimentar e excesso de \\ peso entre trabalhadores de
} restaurantes populares

\author{
Bruna Vieira de Lima COSTA ${ }^{1}$ (D) 0000-0003-3552-7729 \\ Paula Martins HORTA ${ }^{1}$ (iD) 0000-0002-1848-6470 \\ Sabrina Alves RAMOS² (D) 0000-0001-7808-0731
}

A B S T R A C T

\section{Objective}

The objective was to analyze the occurrence and the associated factors with food insecurity and overweight among government-backed economy restaurant workers in one of the biggest cities in Brazil.

\section{Methods}

A sample comprised of 180 individuals and represented $76.0 \%$ of all economy restaurant workers in the city of Belo Horizonte. Food insecurity was identified through the Brazilian Food Security Scale, and excess weight was identified by the body mass index. Data collection included sociodemographic and occupational information, and also health and quality of life perception. Logistic regression models were applied to identify the association.

\section{Results}

Food insecurity and overweight prevalence levels were $24.0 \%$ and $66.7 \%$, respectively. The odds of identifying food insecurity were 2.34 times higher among workers that perceived their quality of life to be regular/poor/very poor and $62.0 \%$ and $74.0 \%$ lower among workers from the $2^{\text {nd }}$ and $3^{\text {rd }}$ tertile of per capita income, respectively. Individuals $\geq 40$ years old (Odds Ratio=2.69, Confidence Interval 95\%:1.33-5.43) and food handlers (Odds Ratio=3.62, Confidence Interval 95\%:1.68-7.81) had higher odds of being classified as overweight compared to reference categories. Workers with higher per capita income presented lower odds of being classified as overweight (Odds Ratio=0.40, Confidence Interval 95\%:0.17-0,96).

\footnotetext{
${ }^{1}$ Universidade Federal de Minas Gerais, Escola de Enfermagem, Departamento de Nutrição. Av. Alfredo Balena, 190, Sta. Efigênia, 30130-100, Belo Horizonte, MG, Brasil. Correspondence to: BVL COSTA. E-mail: <brunavlcosta@gmail.com>.

2 Pontifícia Universidade Católica de Minas Gerais, Departamento de Nutrição, Curso de Nutrição. Belo Horizonte, MG, Brasil.
}

How to cite this article

Costa BVL, Horta PM, Ramos SA. Food insecurity and overweight among government-backed economy restaurant workers. Rev Nutr. 2019;32:e180128. http://dx.doi.org/10.1590/1678-9865201932e180128 


\section{Conclusion}

It was evidenced an occurrence of overweight among government-backed economy restaurant workers, which was associated with age, income and job position. Food insecurity prevalence was associated with income and quality of life perception. Although the sample work in a food and nutritional security promotion program, it is necessary to recommend actions aimed at the promotion of healthy eating habits.

Keywords: Collective feeding. Food security. Occupational health. Overweight.

\section{RESU M O}

\section{Objetivo}

Analisar a ocorrência e os fatores associados à insegurança alimentar e ao excesso de peso entre trabalhadores dos restaurantes populares de uma metrópole brasileira.

\section{Métodos}

Amostra foi composta por 180 indivíduos e representou 76.0\% dos trabalhadores de restaurantes populares de Belo Horizonte. A insegurança alimentar foi identificada pela Escala Brasileira de Insegurança Alimentar e o excesso de peso pelo índice de massa corporal. A coleta de dados incluiu dados sociodemográficos, ocupacionais e de percepção de saúde e qualidade de vida. Modelos de regressão logística foram aplicados para identificar a associação.

\section{Resultados}

As prevalências de insegurança alimentar e do excesso de peso foram de $24.0 \%$ e 66, 7\%, respectivamente. As chances de se identificar insegurança alimentar foram 2,34 vezes maiores entre trabalhadores que consideraram sua qualidade de vida regular/ruim/muito ruim e $62.0 \%$ e $74.0 \%$ menores entre os trabalhadores do $2^{\circ}$ e $3^{\circ}$ tercil da renda per capita, respectivamente. Já indivíduos $\geq 40$ anos (OR=2,69, Intervalo de Confiança 95\%:1,33-5,43) e os manipuladores de alimentos (OR=3,62, Intervalo de Confiança 95\%:1,68-7,81) tiveram mais chances de apresentar excesso de peso. Contudo, os trabalhadores com maior renda per capita (3० tercil) tiveram menores chance de ter excesso de peso (OR=0,40, Intervalo de Confiança 95\%:0,17-0,96).

\section{Conclusão}

Evidenciou-se elevada prevalência de excesso de peso entre os trabalhadores de restaurantes populares, que foi associada à idade, renda e cargo. Já a insegurança alimentar foi associada à renda e qualidade de vida. Ainda que estes trabalhadores estejam inseridos em um programa de promoção da segurança alimentar e nutricional, verificou-se a necessidade de recomendar a realização de ações direcionadas para a promoção da alimentação saudável.

Palavras-chave: Alimentação coletiva. Segurança alimentar. Saúde do Trabalhador. Sobrepeso.

\section{NTRODUCTION}

Human rights are defined as the rights that belong to an individual as a consequence, solely and exclusively, of being human. They are universal, indivisible, interdependent, interrelated and inalienable [1]. As a way of recognizing human rights in the organization of societies, constitutional texts recognize them as social rights. In Brazil, the Federal Constitution of 1988, in its original text, defined as social rights of all Brazilian citizens the access to education, healthcare, work, leisure, personal security, social security, maternity and childhood protection, and assistance to the needy [2].

While the right to food had already been present in discussions of human rights prior to the construction of the 1988 constitution, food was only effectively included as a social right of Brazilians in 2010 [1], through Constitutional Amendment No.64 [3].

In order to ensure compliance with the human right to adequate food in Brazil, actions to promote Segurança Alimentar e Nutricional (SAN, Food and Nutrition Security) have been developed 
in the country [4]. In this sense, SAN is understood as the "fulfillment of the right to regular and permanent access to quality food in sufficient quantities, without compromising access to other essential needs, based on food practices that promote health, to respect the cultural diversity and that are environmentally, economically and socially sustainable" [5].

The Programa Restaurante Popular (RP, Government-backed Economy Restaurant Program) is a strategy to promote SAN and a policy of social inclusion established since 2003 and under the responsibility of the Ministry of Social Development [5]. These restaurants are public spaces for the promotion of food and nutrition, which aim to increase the supply of nutritionally balanced meals at affordable prices to the population that is at risk or social vulnerability [6]. A recent study attested the quality of the meals offered in government-backed economy restaurants and identified the presence of healthy and traditional foods, typical of the Brazilian food culture [7].

The studies related to government-backed economy restaurants are directed to the population that uses the program and seek to identify the nutritional and health profile of these individuals [8-10]. However, government-backed economy restaurant workers also eat their meals in this environment and are at potential risk of social vulnerability, highlighted by low professional qualifications, low educational level and low remuneration [11-13]. In addition, the nutritional profile of workers in the Brazilian public food sector is marked by a high prevalence of overweight individuals (over 60\%) $[14,15]$, an important risk factor for the development of diseases and a marker of noncompliance with Food and Nutrition Security $[5,16]$.

Therefore, doubts arise regarding the food and nutrition security situation of governmentbacked economy restaurant workers and support the investigation of the occurrence of Food Insecurity (FI) and overweight in this population. In this context, the present study is aimed at analyzing the occurrence and factors associated with food insecurity and overweight among government-backed economy restaurant workers from one of the biggest cities in Brazil.

\section{METHODS}

This cross-sectional study was carried out in the city of Belo Horizonte, capital of the State of Minas Gerais, located in the Southeast region of Brazil. The city has a population of 2,375.151 inhabitants in its urban area, being the sixth largest in the country [17].

The analysis unit was composed of the four government-backed economy restaurant units operating in the city at the time of research: (a) Government-backed economy restaurant (I) Herbert de Souza; (b) Government-backed economy restaurant (II) Josué de Castro; (c) Government-backed economy restaurant (III) Maria Regina Nabuco; (d) Government-backed economy restaurant (IV) Dom Mauro Bastos. The administration of the government-backed economy restaurant is the responsibility of the Undersecretariat of Food and Nutrition Security of the City Administration of Belo Horizonte. In the form of self-management, these establishments provide breakfast, lunch and dinner and serve more than 1,000 people per meal [18].

All the workers ( $\mathrm{N}=238$ ) of the four government-backed economy restaurant units, who worked in the day and night shifts, were invited to participate in the study. All active workers $(\mathrm{N}=238)$ were considered eligible, and those ineligible were the ones who had been dismissed from work 
for any reason, the ones who on vacation at the time of data collection, and pregnant women $(n=28 ; 12 \%)$.

Data collection was performed in August and September 2016 by a team of Nutrition academics previously trained and supervised during the process. A semi-structured questionnaire, based on a national survey [19] and validated scales [11,20], was used. Applied by face-to-face interview, the questionnaire contained information about the individual's sociodemographic profile and occupation; their perception of health and quality of life; and food security and nutrition at home. In addition, the data collection included an anthropometric evaluation. All the variables collected by the study are described below.

The household food insecurity situation, defined as limited or uncertain access to food of adequate quantity and quality, was evaluated by the Escala Brasileira de Insegurança Alimentar (EBIA, Brazilian Food Insecurity Scale), translated into Portuguese and validated for the Brazilian population [21]. The long version of the scale was used, which contains 15 or 8 questions, depending on whether or not the interviewed individual have someone under 18 years living in the same household, respectively. This scale classifies the situation of the Brazilian households in: food security, mild food insecurity (family worrying about their ability to obtain food in the future), moderate food insecurity (family need to reduce the quantity, quality and variety of food in order to avoid household food shortage) or severe food insecurity (experiencing household food shortage or hunger) [21]. Considering that the present study aimed to evaluate the occurrence of food insecurity and its associated factors, all categories of the food insecurity scale were grouped, only analyzing the presence or absence of food insecurity.

The prevalence of overweight individuals was obtained with Body Mass Index (BMI). For this, the weight and height of the participants were measured in accordance with the World Health Organization (WHO) standards [22]. Those with a $\mathrm{BMl} \geq 25 \mathrm{~kg} / \mathrm{m}^{2}$ [22] were considered as being overweight.

To know the factors associated with food insecurity and overweight in the sample, data relating to socioeconomic and occupational information, and also relating to their perceptions of health and quality of life, were analyzed.

Socioeconomic data included: sex, age, education, per capita family income (divided into distribution tertiles), marital status (with or without a partner), the condition of being head of household, the existence of dependent children and number of residents in the household.

Regarding their occupation, the job position (food handler and administrative professional), defined according to the Technical Regulation of Good Practices for Food Services of the National Health Surveillance Agency [23] was investigated.

The workers' own perception of health and life quality was evaluated by the questions: "How would you rate your health status?" and "How would you rate your quality of life?"; the following answers were provided: very poor, poor, regular, good, very good. This methodology is used in epidemiological studies to evaluate the quality of life and health of individuals, with results of good validity $[24,25]$. 
These data were tabulated in the Access software (Redmond, Washington DC, United States) (2010) and analyzed using Stata software (Stata Corporation, College Station, Texas, United States) (version 12.0). A descriptive analysis was carried out, obtaining the frequencies of the categorical variables and logistic regression analysis considering the situation of food insecurity and overweight as dependent variables and data related to their socioeconomic and profession information, as well as their perceptions on health and quality of life, as independent variables. Associations that obtained a $p$-value less than 0.25 in the univariate models were included in the multivariate models and maintained in the final model at a significance level of $5 \%(p<0.05)$.

The study was approved by the Research Ethics Committee of the Pontificia Universidade Católica (PUC, Pontifical Catholic University) in the state of Minas Gerais (59118916.0.0000.5137) and the participants read and signed a Free and Informed Consent Form.

\section{RES U L T S}

Of the total eligible staff ( $N=210), 5.0 \%$ refused to participate in the study and $9.0 \%$ did not complete the interview. At the end, 180 individuals were interviewed. Women $(n=112$, $62.0 \%)$, with no partners $(n=97,53.9 \%)$ and with high school education $(n=111,61.7 \%)$ predominated. More than half reported being heads of household ( $n=99 ; 55.3 \%)$ and having dependent children $(n=112 ; 62.2 \%)$. Approximately seven out of ten of them were food handlers (Table 1).

The prevalence of household food insecurity among these workers was $24.0 \%(n=43)$, being $15.6 \%$ rated as mild, $5.6 \%$ rated as moderate and $2.8 \%$ rated as severe. Overweight was present in $66.7 \%(n=120)$ of the sample (Table 1).

In the univariate analysis, the odds of identifying food insecurity were higher among workers who evaluated their health status $(\mathrm{OR}=2.24,95 \% \mathrm{Cl}: 1.03-4.86)$ as regular/poor/very poor their quality of life $(\mathrm{OR}=2.82,95 \% \mathrm{Cl}: 1.31-6.04)$ compared to their respective reference categories. On the other hand, workers with higher per capita income ( $3^{\text {rd }}$ and $2^{\text {nd }}$ tertiles) had lower odds of being in food insecurity situations compared to those in the lowest per capita income bracket $(\mathrm{OR}=0.23,95 \% \mathrm{Cl}: 0.08-0,62$ and $\mathrm{OR}=0.39,95 \% \mathrm{Cl}: 0.18-0.87$, respectively) (Table 2). They remained in the multivariate logistic model, with the variables being: per capita income $\left(2^{\text {nd }}\right.$ tertile: $\mathrm{OR}=0.38,95 \% \mathrm{Cl}: 0.17-0.87,3^{\text {rd }}$ tertile: $\mathrm{OR}=0.26,95 \% \mathrm{Cl}: 0.09(\mathrm{OR}=2.34$, $95 \%$ Cl1.06-5.19), both associated inversely with food insecurity (Table 3).

The odds of being overweight were higher in the univariate models among workers aged 40 years or older $(\mathrm{OR}=2.92,95 \% \mathrm{Cl}: 1.52-5.6)$ and among food handlers $(\mathrm{OR}=4.33$, $95 \% \mathrm{Cl}: 2.12-8.86)$. In addition, workers with higher per capita income ( $3^{\text {rd }}$ tertile) had lower odds of being overweight compared to those in the lowest bracket of per capita income $(\mathrm{OR}=0.37,95 \% \mathrm{Cl}: 0.16-0,84)$ (Table 2$)$. In the multivariate logistic model, the group aged 40 years or older $(\mathrm{OR}=2.69,95 \% \mathrm{Cl}: 1.33-5.43)$ and being food handlers $(\mathrm{OR}=3.62,95 \% \mathrm{Cl}: 1.68$ 7.81), associated with higher odds of being overweight, while the highest monthly per capita income bracket was associated with a lower occurrence of overweight ( $3^{\text {rd }}$ tertile: OR=0.40, 95\% Cl:0.17-0.96) (Table 3). 
Table 1. Characteristics of government-backed economy restaurant workers in the city of Belo Horizonte (MG), Brazil, 2016.

\begin{tabular}{|c|c|}
\hline Characteristics & Frequency (\%) \\
\hline \multicolumn{2}{|l|}{ Sex } \\
\hline Female & 62.0 \\
\hline Male & 38.0 \\
\hline \multicolumn{2}{|l|}{ Age } \\
\hline$\leq 39$ years & 51.1 \\
\hline$\geq 40$ years & 48.9 \\
\hline \multicolumn{2}{|l|}{ Education } \\
\hline High school/college & 61.7 \\
\hline Elementary school & 38.3 \\
\hline \multicolumn{2}{|l|}{ Per capita income } \\
\hline $1^{\text {st }}$ tertile (until BRL 625.00) & 35.3 \\
\hline $2^{\text {nd }}$ tertile (BRL $\left.640.00-B R L 1,000.00\right)$ & 37.2 \\
\hline $3^{\text {rd }}$ tertile (BRL 1,050.00 - BRL 9,000.00) & 27.3 \\
\hline \multicolumn{2}{|l|}{ Marital status } \\
\hline With partner & 46.1 \\
\hline Without partner & 53.9 \\
\hline \multicolumn{2}{|l|}{ Head of household } \\
\hline Yes & 55.3 \\
\hline No & 44.7 \\
\hline \multicolumn{2}{|l|}{ Dependent children } \\
\hline No & 37.8 \\
\hline Yes & 62.2 \\
\hline \multicolumn{2}{|l|}{ Number of residents } \\
\hline$\leq 3$ & 53.6 \\
\hline$\geq 4$ & 46.4 \\
\hline \multicolumn{2}{|l|}{ Position } \\
\hline Non-food handler & 24.4 \\
\hline Food handler & 75.6 \\
\hline \multicolumn{2}{|l|}{ Assessment of health conditions } \\
\hline Very good/good & 78.2 \\
\hline Regular/poor/very poor & 21.8 \\
\hline \multicolumn{2}{|l|}{ Assessment of quality of life } \\
\hline Very good/good & 76.7 \\
\hline Regular/poor/very poor & 23.3 \\
\hline \multicolumn{2}{|l|}{ Food insecurity } \\
\hline Mild food insecurity & 15.6 \\
\hline Moderate food insecurity & 5.6 \\
\hline Severe food insecurity & 2.8 \\
\hline \multicolumn{2}{|l|}{ Overweight } \\
\hline No & 33.3 \\
\hline Yes & 66.7 \\
\hline
\end{tabular}


Table 2. Characteristics of government-backed economy restaurant workers in the city of Belo Horizonte (MG), Brazil, stratified in food insecurity and overweight occurrence. Belo Horizonte (MG), Brazil, 2016.

\begin{tabular}{|c|c|c|c|c|c|c|c|c|}
\hline \multirow{2}{*}{ Characteristics } & \multicolumn{4}{|c|}{ Food insecurity } & \multicolumn{4}{|c|}{ Excess weight } \\
\hline & $(\%)$ & $O R^{*}$ & IC95\% ** & $p$-value & $(\%)$ & $\mathrm{OR}^{*}$ & IC95\%** & $p$-value \\
\hline \multicolumn{9}{|l|}{ Sex } \\
\hline Female & 27.0 & 1 & - & - & 69.4 & 1 & - & - \\
\hline Male & 19.1 & 0.64 & $0.31-1.33$ & 0.230 & 61.8 & 0.71 & $0.38-1.34$ & 0.29 \\
\hline \multicolumn{9}{|l|}{ Age } \\
\hline$\leq 39$ years & 25.0 & 1 & - & - & 55.4 & 1 & - & - \\
\hline$\geq 40$ years & 22.7 & 0.88 & $0.44-1.75$ & 0.720 & 78.4 & 2.92 & $1.52-5.6$ & $<0.01$ \\
\hline \multicolumn{9}{|l|}{ Education } \\
\hline High school/college & 23.4 & 1 & - & - & 65.8 & 1 & - & 0.74 \\
\hline Elementary school & 24.6 & 1.06 & $0.53-2.16$ & 0.850 & 68.1 & 1.11 & $0.59-2.11$ & \\
\hline \multicolumn{9}{|l|}{ Per capita income } \\
\hline $1^{\text {st }}$ tertile & 39.3 & 1 & - & - & 75.4 & 1 & - & - \\
\hline $2^{\text {nd }}$ tertile & 20.3 & 0.39 & $0.18-0.87$ & 0.020 & 68.8 & 0.72 & $0.33-1.58$ & 0.40 \\
\hline $3^{\text {rd }}$ tertile & 12.8 & 0.23 & $0.08-0.62$ & 0.030 & 53.2 & 0.37 & $0.16-0.84$ & 0.01 \\
\hline \multicolumn{9}{|l|}{ Marital status } \\
\hline With partner & 26.5 & 1 & - & - & 69.9 & 1 & - & - \\
\hline Without partner & 21.7 & 0.77 & $0.39-1.52$ & 0.440 & 63.9 & 0.76 & $0.41-1.43$ & 0.39 \\
\hline \multicolumn{9}{|l|}{ Head of household } \\
\hline Yes & 25.3 & 1 & - & - & 65.7 & 1 & - & - \\
\hline No & 22.5 & 0.86 & $0.43-1.72$ & 0.670 & 67.5 & 1.09 & $0.58-2.03$ & 0.79 \\
\hline \multicolumn{9}{|l|}{ Dependent children } \\
\hline No & 20.6 & - & - & - & 58.8 & 1 & - & - \\
\hline Yes & 25.9 & 1.35 & $0.65-2.8$ & 0.410 & 71.4 & 1.75 & $0.93-3.29$ & 0.08 \\
\hline \multicolumn{9}{|l|}{ Number of residents } \\
\hline$\leq 3$ & 20.8 & 1 & - & - & 61.5 & 1 & - & - \\
\hline$\geq 4$ & 27.7 & 1.46 & $0.73-2.89$ & 0.280 & 72.3 & 1.63 & $0.87-3.08$ & 0.12 \\
\hline \multicolumn{9}{|l|}{ Position } \\
\hline Non-food handler & 20.5 & 1 & - & - & 40.9 & 1 & - & - \\
\hline Food handler & 25.0 & 1.29 & $0.57-2.97$ & 0.540 & 75.0 & 4.33 & $2.12-8.86$ & $<0.001$ \\
\hline \multicolumn{9}{|c|}{$\begin{array}{l}\text { Experience working in a government- } \\
\text { backed economy restaurant }\end{array}$} \\
\hline$<1$ year & 84.6 & 1 & - & - & 75.7 & 1 & - & - \\
\hline$\geq 1$ year & 15.4 & 0.45 & $0.22-0.94$ & 0.030 & 24.3 & 1.15 & $0.56-2.40$ & 0.69 \\
\hline \multicolumn{9}{|c|}{ Assessment of health conditions } \\
\hline Very good/good & 20.0 & 1 & - & - & 64.3 & 1 & - & - \\
\hline Regular/poor/very poor & 35.9 & 2.24 & $1.03-4.86$ & 0.004 & 76.9 & 1.85 & $0.81-4.21$ & 0.14 \\
\hline \multicolumn{9}{|c|}{ Assessment of quality of life } \\
\hline Very good/good & 39.0 & 1 & - & - & 65.9 & 1 & - & - \\
\hline Regular/poor/very poor & 18.5 & 2.82 & $1.31-6.04$ & $<0.010$ & 65.9 & 0.99 & $0.48-2.08$ & 0.99 \\
\hline
\end{tabular}

Note: " OR: Odds Ratio; ${ }^{* *}$ IC95\%: Confidence Interval of $95 \%$. 
Table 3. Multivariate logistic model of factors associated with food insecurity and overweight occurrence among workers of government-backed economy restaurants in the city of Belo Horizonte (MG), Brazil, 2016.

\begin{tabular}{|c|c|c|c|}
\hline Variable & $O R^{*}$ & IC95\% ** & $p$-value \\
\hline \multicolumn{4}{|l|}{ Model 1: Food insecurity } \\
\hline \multicolumn{4}{|l|}{ Per capita income } \\
\hline $1^{\text {st }}$ tertile & 1 & - & - \\
\hline $2^{\text {nd }}$ tertile & 0.38 & $0.17-0.87$ & 0.02 \\
\hline $3^{\text {rd }}$ tertile & 0.26 & $0.09-0.71$ & $<0.01$ \\
\hline \multicolumn{4}{|c|}{ Assessment of quality of life } \\
\hline Very good/good & 1 & - & - \\
\hline Regular/poor/very poor & 2.34 & $1.06-5.19$ & 0.04 \\
\hline \multicolumn{4}{|l|}{ Model 2: Overweight } \\
\hline \multicolumn{4}{|l|}{ Age } \\
\hline$\leq 39$ years & 1 & - & - \\
\hline$\geq 40$ years & 2.69 & $1.33-5.43$ & $<0.01$ \\
\hline \multicolumn{4}{|l|}{ Per capita income } \\
\hline $1^{\text {st }}$ tertile & 1 & - & - \\
\hline $2^{\text {nd }}$ tertile & 0.69 & $0.30-1.59$ & 0.39 \\
\hline $3^{\text {rd }}$ tertile & 0.40 & $0.17-0.96$ & 0.04 \\
\hline \multicolumn{4}{|l|}{ Position } \\
\hline Non-food handler & 1 & - & - \\
\hline Food handler & 3.62 & $1.68-7.81$ & $<0.01$ \\
\hline
\end{tabular}

Note: ${ }^{*}$ OR: Odds Ratio; ${ }^{* *}$ IC95\%: Confidence Interval of $95 \%$.

\section{DISCUSSION}

The study showed a high prevalence of overweight individuals among government-backed economy restaurant workers in the city of Belo Horizonte. The occurrence of food insecurity was higher among workers who evaluated their quality of life as being regular/poor/very poor. On the other hand, overweight occurrence was associated with age and position, with a greater chance of identifying this outcome between individuals who are over 40 and food handlers. In addition, the per capita monthly income was inversely associated for both the studied outcomes - food insecurity and overweight.

The prevalence of home-based food insecurity among government-backed economy restaurant workers in Belo Horizonte was lower than in the national surveys conducted in 2004 and $2009-34.9 \%, 30.2 \%$, respectively - and close to the result obtained in 2013 in the survey about the Brazilian population (22.6\%) [26]. In the scope of work, the prevalence of food insecurity identified among government-backed economy restaurant workers in Rio de Janeiro (53.7\%) [27] and among workers in community canteens in Brazil (41.9\%) [28] were significantly higher compared to the present sample.

Characteristics such as a lower proportion of female heads of household and with no children under 18 years, together with the formalization of employment may justify the lower prevalence of food insecurity found in the group [29]. 
However, more than a third of workers reported to earn up to $70 \%$ of the minimum wage. This is a worrying result, since the food insecurity of families receiving less than two minimum wages is ten times higher than of families receiving four or more minimum wages [30]. Household food insecurity is mainly determined by the families' socioeconomic conditions [29,31].

In addition, a higher occurrence of food insecurity was identified among individuals who rated their quality of life in a negative way. In this sense, it is probable that the situation of food insecurity, marked by their low socioeconomic condition, is influencing the perception of the worker's quality of life [32]. Quality of life is defined by the individual's perception of their position in life, the cultural context and the value system in which they live, considering the basic needs of a human being and the feeling of subjective and social well-being [33]. Increased social and economic exposure and vulnerability may negatively impact the perception of individuals' quality of life and health, which in turn impacts food security perceptions [24,25].

Approximately seven out of ten government-backed economy restaurant workers were overweight. The prevalence described above is higher than that observed for the population of Brazilian adults and elderly (53.8\%) and residents of Belo Horizonte (49.6\%) [19]. In the category of professionals of food and nutrition units, a high prevalence of overweight individuals was also found in corporate catering in the southern region of Brazil (78.5\%) [12], in restaurants in a public university (60.9\%) [14] and among public school workers in the city of Belo Horizonte (82.2\%) [13].

The study showed a high prevalence of overweight individuals among government-backed economy restaurant workers in Belo Horizonte. The occurrence of food insecurity was higher among workers who evaluated their quality of life as being regular/poor/very poor. On the other hand, overweight was associated with age and position, with a greater chance of identifying this outcome between individuals over 40 years-old and food handlers. In addition, the per capita monthly income was inversely associated for both the studied outcomes - food insecurity and overweight.

The prevalence of household food insecurity among government-backed economy restaurant workers in Belo Horizonte was lower than those observed in the study. Workers spend most of their lives in the workplace and some factors may negatively affect their ability to make healthy choices related to food and to practice physical activities. Such factors include the lack of worker's influence on work organization and hours worked, and the lack of social support [34]. In meal production units, such as in government-backed economy restaurants, it is easy to have access to food, characterized by the fact of tasting the food during its preparation and the habit of "nibbling" food during the working day, which contributes to weight gain [12], accounts for the greater occurrence of overweight individuals among food handlers compared to non-food handlers.

Higher odds of overweight occurrence were also observed in workers in the lower income strata. In general, poorer individuals are characterized as the most vulnerable to weight gain due to low levels of schooling, poor purchasing power to obtain healthy food, and reduced availability of time and places for practicing physical activities [35].

In addition, the relationship between overweight occurrence and age verified in the present study corroborates the literature. With aging, there is a reduction in the rate of resting metabolism, lean mass, and changes in micronutrient consumption and biological utilization, which have a greater risk of weight gain and accumulation of body fat, as well as bone alterations [36].

It is considered important to propagate this result in view of the association between overweight and an increased absenteeism, turnover, social security costs and incapacity for work [37]. Although they are inserted daily in a program directed to the food and nutrition security, it is 
presumed the necessity to carry out actions directed to the promotion of the healthy food between workers and/or changes in the work place. Measures such as reducing the volume of food available in the workplace; equipment facilities and/or support materials for practicing physical activities, and food and nutrition education are examples of actions to be taken in the logic of health promotion [34]. Aiming at the completeness of the care provided, the scope of actions should be broadened, taking into account the subjects' health problems and needs, with actions developed beyond the boundaries of meal producing units, also favoring the expansion of healthy choices by individuals and collectivities in the territory where they live [34].

Despite the results of this study and its possible impacts, it should be noted that the perception of food insecurity among government-backed economy restaurant workers may be different from the general population, due to their knowledge about a healthy diet and access to various foods during work [27]. The non-participation of workers who had been away from work for more than 30 days may be a source of bias, depending on the "healthy worker effect", since these sick or complaining workers were not addressed [38]. In addition, working conditions were not directly evaluated, however, an earlier study conducted with government-backed economy restaurant workers in the city of Rio de Janeiro pointed out that the majority of workers reported staying most of their working hours in standing posture and listed the following environmental disturbances in descending order of importance: temperature $(90.1 \%)$, noise $(51.2 \%)$, physical effort $(36.2 \%)$ and luminosity $(10.5 \%)$ [11]; that is, unsatisfactory characteristics for a working environment.

\section{CONCLUSION}

A high prevalence of overweight individuals was observed among government-backed economy restaurant workers, which was associated with age, income and position. Food insecurity was associated with income and the individual's perception of quality of life. Changes in the workplace and the adoption of actions and strategies to promote healthy eating habits, including restaurant workers and their dependents, are suggested in order to improve health and well-being, and to prevent the occurrence or progression of diseases and risk factors.

\section{O NTRIBUTORS}

BVL COSTA worked on the conception and design, and also in studying, analyzing and interpreting data and writing the article; PM HORTA participated in the analysis and interpretation of data and in writing the article; SA RAMOS worked on the conception and design, analysis, data interpretation, and in writing the article.

\section{REFEREN CES}

1. Nascimento AL, Andrade SLSL. Segurança alimentar e nutricional: pressupostos para uma nova cidadania? Ciênc Cult. 2010;62(4):34-8.

2. Senado Federal (Brasil). Constituição da República Federativa do Brasil. Brasília: Senado Federal; 1988.

3. Presidência da República (Brasil). Emenda Constitucional nº4 de 24 de fevereiro de 2010. Diário Oficial da União 2010; Seção 1, p.1.

4. Malta DC, Reis AAC, Jaime PC, Morais Neto OI, Silva MMA, Akerman M. Brazil's Unified Health System and the National Health Promotion Policy: Prospects, results, progress and challenges in times of crisis. Ciênc Saúde Coletiva. 2018;23(6):1799-809. 
5. Conferência Nacional de Segurança Alimentar e Nutricional II: a construção da Política Nacional de Segurança Alimentar: relatório final. 2004 [citado 2018 ago 27]. Disponível em: http://www.fomezero.gov.br

6. Ministério do Desenvolvimento Social e Combate à Fome (Brasil). Equipamentos públicos de segurança alimentar e nutricional/Rede SAN/FAURGS/UFRGS/MDS. Porto Alegre: Evangraf; 2011.

7. Carrijo AP, Botelho RBA, Akutsu RCCA, Zandonadi RP. Is what low-income Brazilians are eating in popular restaurants contributing to promote their health? Nutrients. 2018;10(4):414.

8. Souza BFNJ, Marín-León L. Food insecurity among the elderly: Cross-sectional study with soup kitchen users. Rev Nutr. 2013;26(6):679-91. http://dx.doi.org/10.1590/S1415-52732013000600007

9. Godoy KC, Sávio KEO, Akutsu RC, Gubert MB, Botelho RBA. Perfil e situação de insegurança alimentar dos usuários dos Restaurantes Populares no Brasil. Cad Saúde Pública. 2014;30(6):1239-49.

10. Sobrinho FM, Silva YC, Abreu MNS, Pereira SCL, Dias Junior CSD. Fatores determinantes da insegurança alimentar e nutricional: estudo realizado em Restaurantes Populares de Belo Horizonte, Minas Gerais, Brasil. Ciênc Saúde Coletiva. 2014;19(5):601-11.

11. Aguiar OB, Valente JC, Fonseca MJM. Descrição sócio-demográfica, laboral e de saúde dos trabalhadores do setor de serviços de alimentação dos restaurantes populares do estado do Rio de Janeiro. Rev Nutr. 2010;23(6):969-82. http://dx.doi.org/10.1590/\$1415-52732010000600004

12. Luz CM, Proença RPC, Salazar BRO, Galego GN. Working conditions at hospital food service and the development of venous disease of lower limbs. Int J Environ Health Res. 2013;23(6):520-30. http://dx.doi.org/10. 1080/09603123.2013.769203

13. Macedo TR, Anjos AFV, Santos LC, Bethony MFG, Pereira SLC. Fatores associados ao excesso de peso entre manipuladores de alimentos de escolas públicas. Mundo Saúde. 2015;39(2):210-8.

14. Santos K, Ferreira AA, Meira KC, Pierin AMG. Excesso de peso em funcionários de unidades de alimentação e nutrição de uma universidade do Estado de São Paulo. Einsten. 2013;11(4):486-91.

15. Ferriani LO, Martins LV, Pizetta LC, Silva DA. Concordância entre parâmetros antropométricos de obesidade na avaliação do risco cardiovascular em uma amostra de funcionários do setor de alimentação coletiva. Rev Bras Pesq Saúde. 2017;19(3):128-34.

16. Marinho F, Passos VMA, Malta DC, França EB, Abreu DMX, Araújo VEM, et al. Burden of diseases in Brazil, 1990-2016: A systematic subnational analysis for the global burden of disease 2016. Lancet. 2018;392(10149):760-75. http://dx.doi.org/10.1016/S0140-6736(18)31221-2

17. Instituto Brasileiro de Geografia e Estatística. Censo demográfico 2010. Rio de Janeiro: IBGE; 2011 [citado 2018 set 10]. Disponível em: http://censo2010.ibge.gov.br/

18. Prefeitura de Belo Horizonte. Portal de informações e serviços. 2018 [citado 2018 ago 28]. Disponível em: http://portaldeservicos.pbh.gov.br/portalservicos/ view/paginas/apresentaServico.jsf

19. Ministério da Saúde (Brasil). Vigilância de fatores de risco e proteção para doenças crônicas por inquérito telefônico. Brasília: MDS; 2018.

20. Segall-Corrêa AM, Marrin-Leon L. A segurança alimentar no Brasil: proposição e usos da escala brasileira de medida de insegurança alimentar (EBIA) de 2003 a 2009. Segur Aliment Nutr. 2009;16(2):1-19.

21. Sperandio N, Morais DC, Priore SE. Escalas de percepção da insegurança alimentar validadas: a experiência dos países da América Latina e Caribe. Ciênc Saúde Coletiva. 2018;23(2):449-62.

22. World Health Organization. Physical status: The use and interpretation of anthropometry. Report of a WHO Expert Committee. Geneva: World Health Organization; 1995. Technical Report Series, no.854.

23. Agencia Nacional de Vigilância Sanitária (Brasil). Resolução RDC n²16 de 15 de setembro de 2004. Dispõe sobre regulamento técnico de boas práticas para serviços de alimentação. Diário Oficial da União 2004; Seção 1, p.25.

24. Ng N, Hakimi M, Byass P, Wilopo S, Wall S. Health and quality of life among older rural people in Purworejo District, Indonesia. Glob Health Action. 2010;3(1):78-87.

25. Vagetti GC, Moreira NB, Barbosa Filho VC, Oliveira V, Cancian CF, Mazzardo O, et al. Domínios da qualidade de vida associados à percepção de saúde: um estudo com idosas de um programa de atividade física em bairros de baixa renda de Curitiba, Paraná, Brasil. Ciênc Saúde Coletiva. 2013;18(12):3483-93.

26. Instituto Brasileiro de Geografia e Estatística. Pesquisa nacional por amostra de domicílios: segurança alimentar 2013. Rio de Janeiro: IBGE; 2014. 
27. Falcão $A C M L$, Aguiar OB, Fonseca MJM. Association of socioeconomic, labor and health variables related to Food Insecurity in workers of the Popular Restaurants in the city of Rio de Janeiro. Rev Nutr. 2015;28(1):77-87. http://dx.doi.org/10.1590/1415-52732015000100007

28. Godoy K, Sávio KEO, Akutsu RC, Gubert MB, Botelho RBA. Food insecurity and nutritional status of individuals in a socially vulnerable situation in Brazil. Ciênc Saúde Coletiva. 2017;22(2):607-16.

29. Facchini LA, Nunes BP, Motta JV, Tomasi E, Silva SM, Thumé E, et al. Insegurança alimentar no Nordeste e Sul do Brasil: magnitude, fatores associados e padrões de renda per capita para redução das iniquidades. Cad Saúde Pública. 2014;30(1):161-74.

30. Santos JV, Gigante DP, Domingues MR. Prevalência de insegurança alimentar em Pelotas, Rio Grande do Sul, Brasil, e estado nutricional de indivíduos que vivem nesta condição. Cad Saúde Pública. 2010;26(1):41-9.

31. Poblacion AP, Marín-León L, Segall-Corrêa AM, Silveira JA, Taddei JA. Insegurança alimentar em domicílios brasileiros com crianças menores de cinco anos. Cad Saúde Pública. 2014;30(5):1067-78.

32. Hu J, Wallace DC, Tesh AS. Physical activity, obesity, nutritional health and quality of life in low-income hispanic adults with diabetes. J Community Health Nurs. 2010;27(2):70-83.

33. World Health Organization. Development of the World Health Organization WHOQOL-BREF quality of life assessment. Psychol Med. 1998;28(3):551-8.

34. Lassen AD, Fagt S, Lennernäs M, Nyberg M, Haapalar I, Thorsen AV, et al. The impact of worksite interventions promoting healthier food and/or physical activity habits among employees working 'around the clock' hours: A systematic review. Food Nutr Res. 2018;62:1115.

35. Jones-Smith JC, Gordon-Larsen P, Siddiqi A, Popkin BM. Is the burden of overweight shifting to the poor across the globe? Time trends among women in 39 low- and middle-income countries (1991-2008). Int J Obes. 2012;36(8):1114-20.

36. JafariNasabian P, Inglis JE, Reilly W, Kelly OJ, Llitch JZ. Aging human body: Changes in bone, muscle and body fat with consequent changes in nutrient intake. J Endocrinol. 2017;234(1):37-51.

37. Roos E, Laaksonen M, Rahkonen O, Lahelma E, Lallukka T. Relative weight and disability retirement: A prospective cohort study. Scand J Work Environ Health. 2013;39(3):259-67.

38. Chowdhury R, Shah D, Payal AR. Healthy worker effect phenomenon: Revisited with emphasis on statistical methods: A review. Indian J Occup Environ Med. 2017;21(1):2-8. 